\title{
Effects of Newcastle disease vaccine on the liver and antioxidant enzymes of chicks
}

\author{
N.G. Mustafa \\ Department of Physiology, Biochemistry \& Pharmacology, College of Veterinary Medicine, University of Mosul, Mosul, Iraq \\ E-mail: nashaat_ghalib@yahoo.com
}

(Received February 10, 2018; Accepted April 2, 2018)

\begin{abstract}
Newcastle disease is a highly contagious disease of domestic and wild birds result in huge economic losses due to extreme morbidity and mortality. The aim of this paper is to explore the possibility of the harmful impact of Newcastle disease vaccine on certain biochemical profiles regarded to chicken liver. This study conducted during January-April 2014, one day old - 53 chicks were divided into two groups; vaccinated (with Newcastle disease vaccine) group at the age of 1, 3, and 7 days and unvaccinated group. Results show damaging effects of vaccination on the liver glycogen and malondialdehyde concentrations, serum superoxide dismutase, catalase, glutathione peroxidase, gamma-glutamyl transferase, alanine transaminase, and aspartate transaminase activities. In contrast, studied parameters look to return to their usual range at the age of 30 days. From the convincing outcome of our investigation, it can be concluded that Newcastle disease vaccination has a detrimental influence on the liver of chickens, nonetheless this effect can be overwhelmed by the time.
\end{abstract}

Keywords: Newcastle disease vaccination, liver, biochemical profiles, chicks

Available online at http://www.vetmedmosul.com

$$
\begin{aligned}
& \text { تأثير التحصين بلقاح النيوكاسل على الكبد والانزيمات المضادة للأكسدة في الأفراخ } \\
& \text { نشأت غالب مصطفى } \\
& \text { فرع الفسلجة والكيمباء الحباتية والأدوية، كلية الطب البيطري، جامعة الموصل، الموصل، العراق }
\end{aligned}
$$

بعد مرض النيوكاسل مرضاً فيروسياً معدياً جداً ويصيب الطيور الداجنة والبرية مسبباً خسائر اقتصادية كبيرة بفعل النسب العالية

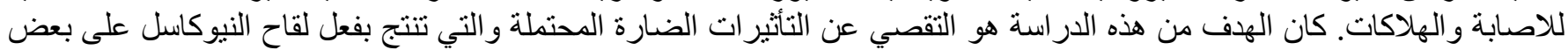

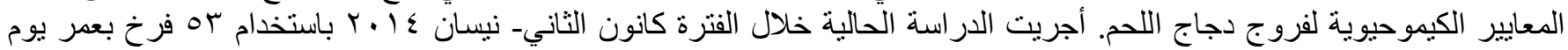

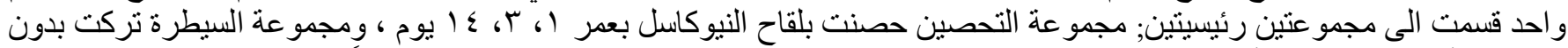

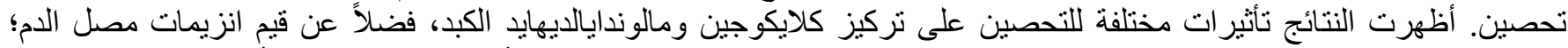

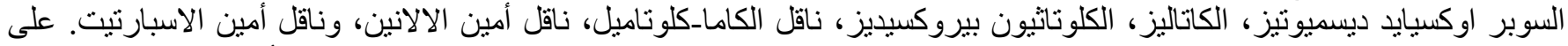

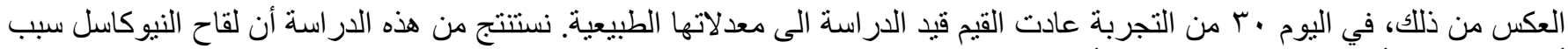

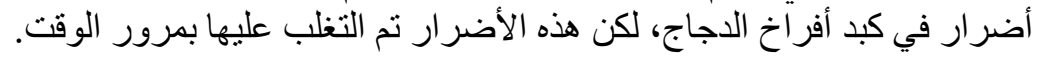

\section{Introduction}

Newcastle disease (ND) has high mortality and economic losses hence it is considered one of the most critical infectious diseases of the chickens (1). The causative agent, the single strand RNA virus, is greatly contagious, widely spread (can infect more than 240 types of domestic and wild birds) (2). The disease was recorded since 1926 in Indonesia, but their name refers to Newcastle in England (3). Like many other viral diseases in human 
and animals, vaccination remains the main strategic choice to face viral infections, thus numerous kinds of vaccine and diverse programs were used (4). On the other hand, the vaccine itself as a live, killed, or attenuated virus has an extensive range of devastating impacts on the host tissues (5), including the liver that may be influenced directly or indirectly by vaccination because it is the central organ in the body responsible for metabolism and detoxification functions (6). Deleterious effects of ND vaccines were documented as stress (particularly respiratory stress in winter) and haemorrhagic spots in the gut and related lymph nodes (1).

The most attention-grabbing stress in animals is the oxidative stress, so in an effort to overcome the stress that results from vaccination, the animal body "fight" by different means and various fortifications (7), these defence system developed by time in animals and sometimes called "antioxidant system", and the living organism try to remain in the balance-state between free radicals and antioxidants (8). Virtually the first and critical line of protection and guard of this system is composed of three key components; 1-Superoxide dismutase (SOD, EC 1.15.1.1), thought to be the main cellular force against stress (9), particularly stress result from free radicals (FR); that is an atom or compound has one or more of unpaired active electrons, FRs are the "natural" product of cellular daily routine activity, but their level will elevate considerably during diseases and stress (10), 2-Catalase (CAT, EC 1.11.1.6), is the enzyme found in most cells and has specific action to catalyse degradation of hydrogen peroxide $\left(\mathrm{H}_{2} \mathrm{O}_{2}\right)$ which is a product of certain oxidation reactions and possess destructive influence to the living cells (11), 3-Glutathion peroxidase (GPx, EC 1.11.1.9) that catalyse the reactions of breakdowns of organic hydroperoxidases and hydrogen peroxide, also it is involved in detoxification processes in the liver (12). The hazard of FRs are due to their extreme ability to attack macromolecules; proteins, nucleic acids, and lipids (13). The key FR in the animal body is reactive oxygen species (ROS), and to less extends reactive nitrogen species (RNS).

From other hands, Alanine transaminase (ALT, EC 2.6.1.2), aspartate transaminase (AST, EC 2.6.1.1), and gamma-glutamyl transferase (GGT, EC 2.3.2.2) are enzymes that estimation of their serum levels is successfully used to investigate liver injury (14).

However, studies on the influence of ND vaccination on the liver are still lacking, so this project was targeted to highlight certain biochemical changes in the chicken liver that may result from ND vaccination.

\section{Materials and methods}

\section{Chicks}

One day old fifty-three Fabrow broiler chicks were used in this project; 21 birds were unvaccinated and considered control group, and 32 birds were vaccinated. All birds housed under standard conditions of temperature, lighting, ventilation, and humidity of this age (15), food and water ad libitum, broilers were fed with suitable diet (Table 1), all chickens appear healthy and no disease conditions were recorded by clinical examination and post-partum inspections. Trials done at the animal house unit in the College of Veterinary Medicine, University of Mosul.

Table 1: Diet composition used in this project to fed chicks

\begin{tabular}{lc}
\hline Composition & $\%$ \\
\hline Corn & 55.3 \\
Barn & 14 \\
Soya bean & 28 \\
Calcium & 0.7 \\
Vitamin-Mineral promix* & 2 \\
\hline Total & $100 \%$ \\
\hline
\end{tabular}

* vitamin D3, 5,000 IU; vitamin A (retinyl acetate), 12,000 IU; vitamin E (DL- $\alpha$-tocopheryl acetate), $30 \mathrm{mg}$; riboflavin, $8 \mathrm{mg}$; thiamine, $1 \mathrm{mg}$; pyridoxine, $3 \mathrm{mg}$; niacin, $20 \mathrm{mg}$; vitamin B12, $0.02 \mathrm{mg}$; pantothenic acid, $20 \mathrm{mg}$; biotin, 0.2 $\mathrm{mg}$; folic acid, $2 \mathrm{mg}$; choline chloride, $480 \mathrm{mg}$; vitamin C, $10 \mathrm{mg}$; iron, $40 \mathrm{mg}$; zinc, $100 \mathrm{mg}$; manganese, $120 \mathrm{mg}$; cobalt, $0.2 \mathrm{mg}$; selenium, $0.3 \mathrm{mg}$; copper, $20 \mathrm{mg}$; and iodine, $1 \mathrm{mg}$.

\section{Vaccination}

At one day of age; lives ND strain clone $30: \geq 6.0 \log ^{10}$ $\mathrm{EID}_{50}$ vaccine (Intervet Co. Australia) was used by coarse spray method of $250 \mathrm{ml}$ of prepared vaccine solution for every 1000 birds, according to the manufacturer's instructions. At 3 days of age; Mukteswar mesogenic strainND vaccine (Intervet Co. Australia) was injected. Finally at 16 days of age; coarse spray LaSota lives ND strain LaSota: $\geq 6.0 \log ^{10} \operatorname{EID}_{50}$ (Intervet Co. Australia) vaccine was used (16).

\section{Blood and liver samples}

Blood samples $(3 \mathrm{ml})$ were taken from wing vein at age of 7, 15 and 30 days, serum separated immediately by blood sample centrifugation at $3000 \times \mathrm{g}$, and kept at $4{ }^{\circ} \mathrm{C}$ until estimation of biochemical profiles. At days 7 and 15 , seven chicks from each group were killed, while at day 30 all birds were killed by slaughter and instantly a small piece of the liver were removed, and kept at $-20^{\circ} \mathrm{C}$ until analysis to determine malondialdehyde and liver glycogen concentrations.

\section{Biochemical analysis}

Liver glycogen concentration (LGC) and liver MDA were determined by using ELISA kits (Cat No. MBS7200725) and (Cat No. MBS620816) respectively. Liver homogenate was prepared according to the instruction 
manual of the above kits. Serum SOD, CAT, GPx, GGT, ALT, and AST were estimated by using commercial ELISA kits; (Cat No. MBS739781), (Cat No. MBS2600286), (Cat No. MBS841503), (Cat No. MBS050744), (Cat No. MBS006424), (Cat No. MBS078171), respectively (17-19).

\section{Statistical analysis}

One way analysis of variance (ANOVA) was used to analyze the results by SPSS windows software program (Ver. 19), and Duncan's test to calculate the differences between groups. Mean and standard deviation was reported, and values of $\mathrm{P} \leq 0.05$ consider significant (20).

\section{Results}

It has been found that $\mathrm{ND}$ vaccination has reasonable effects $(\mathrm{P} \leq 0.05)$ on the studied parameters in the chicks of 7 days (Table 2) in which there is increasing in the concentration of LGC, level of serum GGT, ALT and AST, while serum SOD, CAT, and GPx, and liver MDA are reduced significantly $(\mathrm{P} \leq 0.05)$ when compared with unvaccinated group. Also the most sensible changes in this group were in the serum levels of GPx (91 U/L \pm 6.0$)$, GGT (9.8 U/L \pm 1.1$)$, and AST (93 U/L \pm 3.0$)$ when compared with control group (Table 2). In the group of 15 days, ND vaccination seem to significantly $(\mathrm{P} \leq 0.05)$ elevated LGC, liver MDA, and level of serum SOD, CAT, GPx, GGT, and ALT comparing with control group. In addition to that, results of this group reveal that there are sever changes in the level of serum GGT (11.7 U/L \pm 2.3$)$, CAT (73.1 U/L \pm 3.9), ALT (12 U/L \pm 1.4 ), and AST (94 U/L \pm 4.6 ) (Table $3)$. From other hand, the results of table 4 demonstrate no significant changes in the studied parameters at the age of 30 days, except serum CAT level when compared with control group.

Table 2: Effects of Newcastle disease vaccination on biochemical parameters at the age of 7 days

\begin{tabular}{lcc}
\hline Parameters & $\begin{array}{c}\text { Vaccinated } \\
\text { group } \\
(\mathrm{n}=7)\end{array}$ & $\begin{array}{c}\text { Control } \\
\text { group } \\
(\mathrm{n}=7)\end{array}$ \\
\hline LGC $(\mu \mathrm{g} / \mathrm{mg}$ protein) & $19.8 \pm 2.0 \mathrm{a}$ & $16 \pm 1.8 \mathrm{~b}$ \\
Liver MDA (nmol/mg protein) & $20.3 \pm 0.9 \mathrm{~b}$ & $25.1 \pm 1.3 \mathrm{a}$ \\
SOD (U/L) & $4.4 \pm 1.9 \mathrm{~b}$ & $6.3 \pm 1.3 \mathrm{a}$ \\
CAT (U/L) & $66.0 \pm 3.7 \mathrm{~b}$ & $74.6 \pm 2.8 \mathrm{a}$ \\
GPx (U/L) & $91 \pm 6.0 \mathrm{c}$ & $102.7 \pm 3.2 \mathrm{a}$ \\
GGT (U/L) & $19.1 \pm 2.4 \mathrm{a}$ & $9.8 \pm 1.1 \mathrm{c}$ \\
ALT (U/L) & $16.9 \pm 2.2 \mathrm{a}$ & $13 \pm 1.1 \mathrm{~b}$ \\
AST (U/L) & $111 \pm 2.9 \mathrm{a}$ & $93 \pm 3.0 \mathrm{c}$ \\
\hline
\end{tabular}

Values are expressed as mean \pm SD and the different letters mean significant differences at $\mathrm{P} \leq 0.05$ between groups to the same parameter.
Table 3: Effects of Newcastle disease vaccination on biochemical parameters at the age of 15 days

\begin{tabular}{lll}
\hline Parameters & $\begin{array}{c}\text { Vaccinated } \\
\text { group } \\
(\mathrm{n}=7)\end{array}$ & $\begin{array}{c}\text { Control } \\
\text { group } \\
(\mathrm{n}=7)\end{array}$ \\
\hline LGC ( $\mu$ g/mg protein) & $18.9 \pm 1.4 \mathrm{a}$ & $16 \pm 1.0 \mathrm{~b}$ \\
Liver MDA (nmol/mg protein) & $37.2 \pm 2.1 \mathrm{a}$ & $30.3 \pm 3.4 \mathrm{~b}$ \\
SOD (U/L) & $5.2 \pm 0.9 \mathrm{a}$ & $4.1 \pm 1.1 \mathrm{~b}$ \\
CAT (U/L) & $80.3 \pm 4.7 \mathrm{a}$ & $73.1 \pm 3.9 \mathrm{c}$ \\
GPx (U/L) & $104 \pm 5.2 \mathrm{a}$ & $98 \pm 5.0 \mathrm{~b}$ \\
GGT (U/L) & $37 \pm 3.7 \mathrm{a}$ & $11.7 \pm 2.3 \mathrm{~d}$ \\
ALT (U/L) & $18 \pm 1.6 \mathrm{a}$ & $12 \pm 1.4 \mathrm{c}$ \\
AST (U/L) & $114 \pm 4.0 \mathrm{a}$ & $94 \pm 4.6 \mathrm{c}$ \\
\hline
\end{tabular}

Values are expressed as mean \pm SD and the different letters mean significant differences at $\mathrm{P} \leq 0.05$ between groups to the same parameter.

Table 4: Effects of Newcastle disease vaccination on biochemical parameters at the age of 30 days

\begin{tabular}{lll}
\hline Parameters & $\begin{array}{c}\text { Vaccinated } \\
\text { group } \\
(\mathrm{n}=7)\end{array}$ & $\begin{array}{c}\text { Control } \\
\text { group } \\
(\mathrm{n}=7)\end{array}$ \\
\hline LGC ( $\mu$ g/mg protein) & $16 \pm 1.5 \mathrm{a}$ & $17 \pm 1.7 \mathrm{a}$ \\
Liver MDA (nmol/mg protein) & $29.0 \pm 2.2 \mathrm{a}$ & $31.4 \pm 3.0 \mathrm{a}$ \\
SOD (U/L) & $4.6 \pm 1.2 \mathrm{a}$ & $4.2 \pm 1.5 \mathrm{a}$ \\
CAT (U/L) & $77.4 \pm 3.9 \mathrm{a}$ & $72.2 \pm 3.6 \mathrm{~b}$ \\
GPx (U/L) & $100 \pm 4.7 \mathrm{a}$ & $97 \pm 4.3 \mathrm{a}$ \\
GGT (U/L) & $17.9 \pm 3.6 \mathrm{a}$ & $14.0 \pm 3.3 \mathrm{a}$ \\
ALT (U/L) & $13 \pm 1.1 \mathrm{a}$ & $13 \pm 1.2 \mathrm{a}$ \\
AST (U/L) & $93 \pm 5.1 \mathrm{a}$ & $95 \pm 4.4 \mathrm{a}$ \\
\hline
\end{tabular}

Values are expressed as mean \pm SD and the different letters mean significant differences at $\mathrm{P} \leq 0.05$ between groups to the same parameter.

\section{Discussion}

In this study for the first time we propose ND vaccination on liver glycogen and MDA concentrations, and serum SOD, CAT, GPx, GGT, ALT, and AST.

An important implication of our results is that ND vaccination changes the level of studied parameters, revealing it is deleterious influence directly after vaccination, (group of 7 days, see Table 2), and remarkably there is more impact feat to peak at 15 day (Table 3) and this may be due to the accumulative damage effects of three doses of vaccine with insufficient counteracted by antioxidants (21).

Recently authors suggest that ND vaccination can cause various grades of stress (22), those authors found that ND vaccination decrease body weight gain and food conversion efficiency of chicks aged 1-21 days. However damaging 
effects of stress may result from amplified level of ROS and/or reduced antioxidant levels $(23,24)$. In various types of liver injury there are different degrees of oxidative stress that may impact directly liver specific enzymes, particularly glycogen synthase kinase (GSK) enzyme that regulate glycogen synthesis (25). Remarkably, oxidative stress can control hepatic cell proliferations and apoptosis, in part by regulating the activity of GSK (26-28), also by regulating several cell signalling pathways like $\beta$ catenin/Wnt (29), p53 (30), NF-kB (nuclear factor kappa of activated B cells) (31), MAPK (mitogen-activated protein kinase) (32), and PI3K (phosphatidylinositide 3-kinase) (33). However, oxidative stress could be exacerbates hepatotoxicity by upstream the activity of GSK enzyme, and this fact may elucidate our result of high level of LGC in ND vaccinated groups at 7 and 15 days (see Table 2 and 3 ).

Our finding elevated level of liver MDA is disagree with Wei et al. (34) who's documented depressed level of MDA, SOD, CAT, GPx in 7 days chicks. Our result may be due to instant and sever effect of two doses of vaccination on the liver at 1 and 3 days of age, and this outcome agree with $\mathrm{Du}$ et al. (35) who suggest that sever oxidative stress cause massive changes in the hepatocytes as lipid peroxidation, mitochondrial dysfunction, DNA damage, and apoptosis (35).

With the time, adaptation and compensatory ordering reaction of bird body may cause rising level of liver MDA, serum SOD, CAT, GPx at the age of 15 days (Table 3 ) in an effort to defeat the sequel of oxidative stress. These results are consistent with other studies $(36,37)$ which have shown that serum SOD, CAT, GPx and liver MDA elevation were associated to oxidative stress condition. On the other hand, high level of serum GGT, ALT, and AST indicate liver damage leading to liberation of these enzymes into blood, these data are concur with Korolczuk et al. (36) but disagree with Albano (37) who documented depressed level of ALT and AST related to liver oxidative damage. Whereas Kudair and Al-Hussary (38) found vaccination (many vaccines in addition to ND vaccine), elevated level of AST but ALT remain unchanged, other authors recognized that the elevated level of serum GGT, as a liver specific enzyme, was related to the severity of hepatotoxicity (39).

In contrast, at the end of the experiments (30 days), considered parameters seem to back to their ordinary range, the most likely explanation of this result may be refer to overcoming of body argument mechanisms against harmful effects of vaccine and the adaptation of birds by the time to the stress of vaccination.

In conclusion, our results have clearly shown that ND vaccination can be consider as a stress factor and has harmful influence on the liver of broiler chickens, but these damage effects can be overcome by the time. However, further studies of the issue are still required.

\section{Acknowledgement}

The author would like to thanks the College of Veterinary Medicine / University of Mosul / IRAQ, for it is support in implementing this project.

\section{References}

1. Swayne DE. Diseases of Poultry. $13^{\text {th }}$ ed. Iowa, USA: WileyBlackwell Publisher; 2013.

2. Cattoli G, Susta L, Terregino C, Brown C. Newcastle disease: a review of field recognition and current methods of laboratory detection. J Vet Diagn Invest. 2011;23(4):637-656.

3. Macpherson LW. Some observations on the epizootiology of Newcasle disease. Can J Comp Med Vet Sci. 1956;20(5):155-168.

4. Dortmans JC, Peeters BP, Koch G. Newcastle disease virus outbreaks: vaccine mismatch or inadequate application? Vet Microbiol. 2012;160(1-2):17-22.

5. Kapczynski DR, Afonso CL, Miller PJ. Immune responses of poultry to Newcastle disease virus. Dev Comp Immunol. 2013;41:447-453.

6. Rodwell VW, Bender DA, Botham KM, Kennelly PJ, Weil PA. Harper's Illustrated Review of Biochemistry. $30^{\text {th }}$ ed. USA. McGrawHill education; 2015.

7. Lykkesfeldt J, Svendsen O. Oxidants and antioxidants in diseases: oxidative stress in farm animals. Vet J. 2007;173(3):502-511.

8. Niki E. Antioxidants: basic principles, emerging concepts, and problems. Biomed J. 2014;37:106-111.

9. Surai PF. Antioxidant systems in poultry biology: superoxide dismutase. J Anim Res Nutr. 2016;1(1):1-17.

10. Halliwell B. Free radicals and antioxidants: updating a personal view. Nutr Rev. 2012;70(5):257-265.

11. Kabel AM. Free radicals and antioxidants: role of enzymes and nutrition. World J Nutr Health. 2014;2(3):35-38.

12. Katar M, Ozugurlu AF, Ozyurt H, Benli I. Evaluation of glutathione peroxidase and superoxide dismutase enzyme polymorphisms in celiac disease patients. Gen Mol Res. 2014;13(1):1030-1037.

13. Zhang J, Hou X, Ahmad H, Zhang H, Zhang L, Tian W. Assessment of free radicals scavenging activity of seven natural pigments and protective effects in AAPH-challenged chicken erythrocytes. J Food Chem. 2014;145(7):57-65.

14. Ghouri N, Preiss D, Sattar N. Liver enzymes, nonalcoholic fatty liver disease, and incident cardiovascular disease: a narrative review and clinical perspective of prospective data. Hepatology. 2010;52(3):1156-1161.

15. Tawfik FK, Mustafa NG. Effects of coriander, thyme, vanadyl and tungstate, on some biochemical parameters in broiler chickens ALT, AST and liver glycogen concentration Iraqi J Vet Sci. 2012;16(II):7175 .

16. Senne DA, King DJ, Kapczynski DR. Control of Newcastle disease by vaccination. Dev Biol (Basel). 2004;119:165-170.

17. Plummer DT. An Introduction to Practical Biochemistry. $3^{\text {rd }}$ ed. Indian edition. McGraw Hill Education; 2017.

18. Burtis CA, Ashwood ER, Bruns DE. Tietz Textbook of Clinical Chemistry and Molecular Diagnostics. $4^{\text {th }}$ ed. Missouri, USA. Elsevier Saunders; 2006.

19. Wilson K, Walker J. Principles and Techniques of Biochemistry and Molecular Biology. 7th ed. Cambridge University Press; 2010.

20. Bass I. Six Sigma Statistics with Excel and Minitab. $1^{\text {st }}$ ed. New York, USA. McGraw Hill Co.; 2007.

21. Valdecantos MP, Perez-Matute P, Martínez JA. Obesity and oxidative stress: role of antioxidants supplementation. Rev Invest Clin. 2009;61(2):127-139.

22. Wang X, Zhou Q, Shen J, Yao J, Yang X. Effect of difference doses of Newcastle disease vaccine immunization on growth performance, 
plasma variables and immune response of broilers. J Anim Sci Biotechnol. 2015;6(1):20-25

23. Dryden GW Jr, Deaciuc I, Arteel G, McClain CJ. Clinical implications of oxidative stress and antioxidant therapy. Curr Gastroenterol Rep. 2005;7(4):308-316.

24. Han D, Hanawa N, Saberi B, Kaplowitz N. Mechanisms of liver injury. III. Role of glutathione redox status in liver injury. Am J Physiol Gastrointest Liver Physiol. 2006;291:G1-G7.

25. Czaja Mark J. Cell signaling in oxidative stress-induced liver injury. Semin Liver Dis. 2007;27:378-389.

26. Lee KY, Koh SH, Noh MY, Park KW, Lee YJ, Kim SH. Glycogen synthase kinase-3b activity plays very important roles in determining the fate of oxidative stress-inflicted neuronal cells. Brain Res. 2007;1129:89-99.

27. Koh SH, Kim SH, Kwon H, Park Y, Kim KS, Song CW, Kim J, Kim $\mathrm{MH}, \mathrm{Yu} \mathrm{HJ}$, Henkel JS, et al. Epigallocatechin gallate protects nerve growth factor differentiated PC12 cells from oxidative-radical-stressinduced apoptosis through its effect on phosphoinositide 3-kinase/Akt and glycogen synthase kinase-3. Brain Res Mol Brain Res. 2003;118(1-2):72-81.

28. Schafer M, Goodenough S, Moosmann B, Behl C. Inhibition of glycogen synthase kinase $3 \mathrm{~b}$ is involved in the resistance to oxidative stress in neuronal HT22 cells. Brain Res. 2004; 1005 (1-2):84-89.

29. Dadhania VP, Bhushan B, Apte U, Mehendale HM. Wnt/ $\beta$-Catenin Signaling Drives Thioacetamide-Mediated Heteroprotection Against Acetaminophen-Induced Lethal Liver Injury. Dose Response. 2015;15(1): 1559325817690287.

30. Beyfuss K, Hood DA. A systematic review of $p 53$ regulation of oxidative stress in skeletal muscle. Redox Report 2018;23(1):100-117.

31. Udwan K, Brideau G, Fila M, Edwards A, Vogt B, Doucet A. Oxidative stress and nuclear factor $\kappa \mathrm{B}(\mathrm{NF}-\mathrm{\kappa B})$ increase peritoneal filtration and contribute to ascites formation in nephrotic syndrome. $\mathrm{J}$ Biol Chem. 2016;291(21):11105-11113.

32. Lili Yang L, Wua D, Cederbauma AI. CYP2E1, oxidative stress and MAPK signaling pathways in alcohol-induced hepatotoxicity. J Biochem Pharm Res. 2014;2(2):74-90.

33. Mobaser MA, Gonzalez-Rodriguez A, Santamaria B, Romas S, Martin MA, Goya L, Rada P, Letzig L, James LP, Cuadrado A, et al. Protein tyrosine phosphatase 1B modulates GSK3 $\beta / N r f 2$ and IGFIR signaling pathways in acetaminophen-induced hepatotoxicity. Cell Death Dis. 2013;4,e626:1-13

34. Wei L, Ren F, Zhang X, Wen T, Shi H, Zheng S, Zhang J, Chen Y. Oxidative stress promotes D-GalN/LPS-induced acute hepatotoxicity by increasing glycogen synthase kinase $3 b$ activity. Inflamm Res. 2014; 63:485-494.

35. Du X, Chen L, Huang D, Peng Z, Zhao C, Zhang Y, Zhu Y, Wang Z, Li X, Liu G. Elevated Apoptosis in the Liver of Dairy Cows with Ketosis. Cell Physiol Biochem. 2017;43:568-578.

36. Korolczuk A, Caban K, Amarowicz M, Czechowska G, Irla-Miduch J. Oxidative Stress and Liver Morphology in Experimental Cyclosporine A-Induced Hepatotoxicity. Bio Med Res International. 2016;(2016):19.

37. Albano E. Oxidative mechanisms in the pathogenesis of alcoholic liver disease. Mol Aspects Med. 2008;29(1-2):9-16.

38. Kudair IM, Al-Hussary NAJ. Effect of vaccination on some biochemical parameters in broiler chickens. Iraqi $\mathrm{J}$ Vet Sci. 2010;24(2):59-64.

39. Fernandez A, Verde MT, Gascon M, Ramos J, Gomez J, Luco DF, Chavez G. Variations of clinical biochemical parameters of laying hens and broiler chickens fed aflatoxin containing feed. Avian Pathol. 1994;23(1):37-47. 